Dunamis: Jurnal Teologi dan Pendidikan Kristiani

Volume 4, Nomor 1 (Oktober 2019)

ISSN 2541-3937 (print), 2541-3945 (online)

http://www.sttintheos.ac.id/e-journal/index.php/dunamis

\title{
Studi Analisis Kontekstual Ajaran Karunia Nubuat Rasul Paulus sebagai Dasar Evaluasi Kritis terhadap Fenomena Bernubuat di Gereja Beraliran Karismatik
}

\author{
Kosma Manurung \\ Program Studi Magister Teologi STT Intheos Surakarta \\ kosmamanurung@sttintheos.ac.id
}

\begin{abstract}
The purpose of this study was to evaluate the phenomenon of prophecy in Charismatic churches. The method used in writing this atricle was combining the analysis of the prophetic texts of Paul's writings and the study of phenomenology. Through this research it was revealed that the practice of prophecy is widely practiced among Charismatic churches in the city of Semarang. The results showed that the pastors in the Charismatic churches need to have a correct understanding of the practice of prophecy, especially understanding Paul's teaching about prophecy, in order to avoid the adverse effects for the church caused by the practice of prophecy.
\end{abstract}

Keywords: gift of prophecy; critic evaluation; phenomenon of prophecy

\begin{abstract}
Abstrak
Tujuan penelitian ini adalah untuk mengevaluasi fenomena nubuatan yang marak di gereja Karismatik. Ada pun metode yang digunakan dalam penulisan atrikel ini adalah memadukan analisis teks-teks nubuatan tulisan Paulus dan studi fenomenologi. Melalui penelitian ini terungkap bahwa praktik bernubuat banyak dipraktikan di kalangan gereja beraliran Karismatik di kota Semarang. Hasil penelitian menunjukkan bahwa pendeta-pendeta di kalangan gereja Karismatik perlu memiliki pemahaman yang benar tentang praktik bernubuat, khususnya memahami dengan benar pengajaran Paulus tentang nubuatan, supaya terhindar dari dampak yang merugikan gereja yang disebabkan oleh praktek nubuatan tersebut.
\end{abstract}

Kata kunci: karunia bernubuat; evaluasi kritis; fenomena bernubuat 


\section{PENDAHULUAN}

Gereja beraliran Karismatik adalah gereja yang mempercayai bahwa karya Tuhan berupa karunia-karunia Roh Kudus dan mujizat yang ada dalam Alkitab masih bisa terjadi di zaman ini. Aliran ini menekankan pengalaman supra natural dengan Roh Kudus, pelayanan berdasarkan karunia-karunia Roh Kudus, menekankan mujizat, dan tanda-tanda ajaib. ${ }^{1}$ Terkait dengan karunia bernubuat yang rasul Paulus ajarkan peneliti menemukan karunia bernubuat ini cukup banyak dipraktikkan di kalangan gereja beraliran Karismatik di kota Semarang yang perlu dikaji secara mendalam apakah nubuatan tersebut Alkitabiah ataukah tidak? Bahkan ada nubuatan-nubuatan yang tidak seharusnya diucapkan karena apabila nubuatan itu diikuti akan menimbulkan dampak negatif yang berupa perpecahan dalam tubuh Kristus. Karunia nubuat seharusnya digunakan untuk pelayanan yang menyatukan tubuh Kristus, dan bukan sebaliknya menimbulkan perpecahan diantara tubuh Kristus. ${ }^{2}$

Nubuat terkait fenomena alam adalah contoh nubuat yang peneliti temukan

\footnotetext{
${ }^{1}$ Daniel Sutoyo, "The Charismatic Movement," Jurnal Antusias 1, no. 2 (2011): 29-40, accessed October 20, 2019, https://sttintheos.ac.id/ejournal/index.php/antusias/article/view/82. ${ }^{2}$ Yushak Soesilo, "Pengalaman Pribadi Dengan Roh Kudus Sebagai Indikator Kualitas Pelayanan,"
}

di kalangan gereja beraliran Karismatik di kota Semarang. Tentu saja tidak semua kalangan dari gereja beraliran Karismatik mengaitkan fenomena alam dengan sesuatu yang supra natural atau malah mengaitkan hal itu dengan Kitab Suci. Misalnya fenomena bulan darah (blood moon) beberapa waktu dikaitkan dengan kedatangan Yesus kedua kali yang segera dalam waktu dekat. Ada lagi mengenai bunyi sangkakala yang kata beberapa dari mereka yang bergabung di komunitas tertentu dari kalangan gereja beraliran Karismatik ini mereka mendengar dibanyak tempat bukan saja di Indonesia tapi dibeberapa negara lain menurut mereka juga terdengar suara sangkakala ini, dan mengaitkan dengan kedatangan Yesus kedua kali juga.

Nubuat tentang pasangan roh atau yang lebih dikenal dengan kawin roh merupakan nubuat lainnya yang terjadi di kalangan gereja beraliran Karismatik di kota Semarang. Adapun yang dimaksud kawin roh disini adalah secara fisik orang tersebut sudah punya suami dan istri yang sah dihadapan Tuhan dan manusia namun secara rohani mereka juga mempunyai suami dan istri yang bukan istri/ suami fisik

Jurnal Antusias 1, no. 3 (September 1, 2011): 109117, accessed March 4, 2018, http://sttintheos.ac.id/ejournal/index.php/antusias/article/view/79/78. 
mereka. Kawin roh ini menjadi isu yang hangat ketika diisukan bahwa salah satu gembala sidang gereja besar di Semarang dinubuatkan oleh seorang hamba Tuhan lainnya bahwa istri rohaninya adalah seorang wanita lain yang juga hamba Tuhan dari daerah Bekasi. Isu mengenai kawin roh ini begitu menyebar cepat dan dibicarakan oleh orang percaya berbagai kalangan entah itu dengan maksud baik, merendahkan, dan bahkan mungkin dengan maksud untuk menyerang.

$$
\text { Nubuat tentang posisi }
$$
kepemimpinan merupakan nubuatan selanjutnya yang terjadi di kalangan gereja beraliran Karismatik di kota Semarang. Nubuat diucapkan oleh hamba Tuhan terkait dengan pergantian kepemimpinan di sebuah gereja lokal di kota Semarang. Dimana dalam nubuatan tersebut isinya melarang orang percaya untuk datang ke gereja tertentu dikarenakan posisi gembala yang sekarang bukan merupakan orang yang Tuhan urapi untuk menduduki posisi gembala. Padahal oleh sinode gereja tersebut, sang gembala yang sekaranglah yang ditunjuk untuk mengantikan posisi gembala yang sudah meninggal. Nubuatan yang terkesan mengada-ngada dan tidak memiliki dasar yang kuat dalam Alkitab

\footnotetext{
${ }^{3}$ Yohanes Krismantyo Susanta, "“Menjadi Sesama Manusia' Persahabatan Sebagai Tema Teologis Dan Implikasinya Bagi Kehidupan Bergereja,"
}

sehingga merugikan orang percaya yang mendengarkan nubuat ini. Sepertinya orang yang mengucapkan nubuatan ini tidak menghormati otoritas dan bukanlah seorang yang taat pada kepemimpinan. Seharusnya orang percaya diajarkan bahwa salah satu prioritas dalam bergereja lokal adalah bagaimana taat pada pemimpin, menghormati otoritas kepemimpinan, dan ramah baik kepada sesama orang percaya maupun orang yang belum percaya karena hal ini mencerminkan kualitas manusia yang luhur. ${ }^{3}$

Mengingat begitu maraknya nubuatan yang terjadi dan dampak yang bisa ditimbulkan apabila nubuatan ini disalah gunakan oleh orang yang tidak bertanggung jawab, maka dari itu peneliti berpendapat bahwa sudah seharusnya setiap nubuat yang diucapkan dievaluasi. Alkitab adalah sumber kebenaran tertulis tertinggi yang dimiliki oleh orang percaya. Maka, sudah seharusnyalah Alkitab juga menjadi alat ukur untuk mengevaluasi nubuatan. Teks Alkitab sebagai alat evaluasi yang peneliti maksudkan dalam tulisan ini dikhususkan pada surat-surat dari rasul Paulus. Tujuan penelitian ini adalah menerapkan prinsip-prinsip karunia nubuat dalam tulisan rasul Paulus dan dijadikan 
alat ukur untuk mengevaluasi setiap nubuat termasuk juga mengevaluasi secara kritis fenomena bernubuat yang terjadi di kalangan gereja beraliran Karismatik sekota Semarang. Bagi rasul Paulus terutama dalam tulisannya kepada jemaat di Korintus, evaluasi mutlak diperlukan ketika karunia nubuat dipraktekan dalam suatu komunitas orang percaya.

\section{METODE PENELITIAN}

Metode penelitian dalam tulisan ini menggunakan metode kualitatif dengan jenis pendekatan mengkombinasikan analisis teks dengan fenomenologi transendal. Analisis teks peneliti gunakan untuk menganalisis teks-teks dari tulisan rasul Paulus yang terkait dengan nubuatan terutama dalam tulisannya kepada jemaat di Korintus yang nantinya akan digunakan sebagai dasar evaluasi kritis terhadap fenomena bernubuat. Sedangkan pendekatan fenomenologi transendal peneliti gunakan untuk mencari data lapangan berupa wawancara dengan enam orang pemimpin gereja yang memahami terkait topik karunia nubuat di gereja beraliran karismatik yang ada di Semarang. Creswell menyatakan bahwa Fenomenologi transendal kurang berfokus pada penafsiran

\footnotetext{
${ }^{4}$ John W. Creswell, Penelitian Kualitatif Dan Design Riset (Yogyakarta: Pustaka Pelajar, 2015), 110.

${ }^{5}$ Kosma Manurung, "Studi Analisis Kontekstual Ajaran Karunia Nubuat Rasul Paulus Sebagai Dasar
}

dari peneliti, namun lebih berfokus pada deskripsi tentang pengalaman dari para partisipan tersebut. ${ }^{4}$

Waktu penelitian dalam artikel ini dimulai bulan September 2016 sampai dengan Desember 2017. Tempat penelitian dalam artikel ini adalah gereja-gereja beraliran Karismatik yang ada di kota Semarang.

\section{HASIL DAN PEMBAHASAN}

\section{Ajaran Karunia Nubuat Rasul Paulus}

Karunia nubuat adalah suatu kemampuan yang asalnya dari Allah melalui karya Roh Kudus yang memampukan orang percaya untuk menerima dan menyampaikan pesan Allah untuk disampaikan kepada umat Allah. ${ }^{5}$ Paulus menjelaskan bahwa karunia rohani bukan menjadi hak khusus sebagian pihak atau sekelompok kecil manusia melainkan milik setiap orang percaya yang telah menerima Yesus Kristus sebagai Tuhan dan Juruselamat. Hal ini berarti bahwa setiap orang percaya pasti memiliki satu karunia rohani. 1 Korintus 12:1 dan Efesus 4:7 menyatakan bahwa karunia rohani diberikan kepada tiap orang. Tulisan Paulus merupakan merupakan tanggapan atas

\footnotetext{
Evaluasi Kritis Terhadap Fenomena Bernubuat Di Gereja Beraliran Karismatik Se-Kota Semarang" (STT Berita Hidup, 2018), 37-38.
} 
situasi yang dialami jemaat sebagai jawaban atas setiap pergumulan umat Allah. ${ }^{6}$ Selain itu, Paulus mengembangkan gagasan tentang gereja sebagai tubuh Kristus dan dalam tubuh itu setiap anggota memiliki satu fungsi yang berlainan dengan anggota lainnya. Penjelasan Paulus ini memperlihatkan dua hal yaitu Roh Kudus sebagai sumber dari karunia dan orang percaya sebagai pihak yang menerima karunia. Terkait dengan nubuat, dalam hal ini Roh Kudus merupakan sumber karunia bernubuat. Penggunaan karunia ini tentunya digunakan bukan untuk kepentingan pribadi orang yang memiliki karunia tetapi penggunaan karunia nubuat ini sudah seharusnya sesuai dengan kehendak Roh Kudus.

Karunia rohani yang rasul Paulus bicarakan di sini berbeda dengan bakat manusia. Karunia rohani itu karya Roh Kudus sementara bakat atau talenta lahir dari kemampuan manusia. Paulus memperjelas hal tersebut dalam 1 Korintus 12:11, "Tetapi semuanya ini dikerjakan oleh Roh yang satu dan yang sama, yaitu memberikan karunia kepada tiap-tiap orang secara khusus, seperti yang dikehendakiNya." Penekanannya adalah pada kehendak Roh bukan pada kehendak atau kemauan

\footnotetext{
${ }^{6}$ Suharso, "Kekhasan Eskhatologi Rasul Paulus," EL-SHADDAY (Jurnal Teologi) 1, no. 1 (2017): 65-75.
}

manusia. Namun, Paulus mendorong orang percaya untuk mendapatkan karuniakarunia rohani secara khusus karunia bernubuat (1 Kor. 14:1). Ketika orang percaya gagal menghidupi karunia-karunia rohani maka gerejalah yang paling merasakan akibat tidak adanya karuniakarunia Allah yang indah yang dikirim dari surga ini. Gereja akan menjadi miskin dan lemah. ${ }^{7}$ Gereja juga akan merasakan dampak kemiskinan dan kelemaham rohani jika karunia nubuat tidak ditempatkan pada tempat yang semestinya seperti yang firman Tuhan ajarkan.

Jika mengkaji lebih dalam tentang tulisan-tulisan rasul Paulus terkait tentang nubuat baik itu nubuat dalam jemaat di Korintus (1 Kor. 12:10; 14:1-5). Nubuat dalam 1 Korintus 12:10 merupakan contoh dari nubuat dalam tulisan Paulus. Peneliti mengkaji lebih jauh lagi pengertian nubuat dan mengacu pada bahasa aslinya yaitu bahasa Yunani prophèteia, nubuat memiliki pengertian bukanlah sekedar ucapan biasa tetapi ucapan yang bersifat ilahi dan mendeklarasikan maksud dan tujuan Tuhan. Sangat jelas disini bahwa nubuat atau karunia bernubuat tidak boleh digunakan dengan sembarangan karena nubuat mendeklarasikan maksud dan tujuan Tuhan.

\footnotetext{
${ }^{7}$ Paul Ang and Christina Ang, Charisma (Yogyakarta: Andi Offset, 2013), 3.
} 
Pengamatan secara teliti mengenai 1 Korintus 14:1-25 memperlihatkan bahwa perikop ini membicarakan dua topik pokok dari karunia Roh yaitu karunia bahasa roh dan karunia bernubuat. Paulus menasihati jemaat di Korintus supaya dalam ibadahibadah atau ketika dalam suatu perkumpulan orang percaya di Korintus di minta bukan sekedar berbahasa roh. Jemaat diminta juga mulai menghidupi karunia untuk bernubuat.

Peneliti berusaha menganalisis lebih jauh bagaimana sebenarnya pandangan Paulus mengenai nubuat terkait dengan jemaat di Korintus. Tujuan yang dimaksud adalah bersifat membangun, menasihati dan menghibur jemaat. Kata yang di gunakan untuk membangun berasal dari bahasa Yunani oikodome yang juga berarti membangun keatas, mempromosikan seseorang ke dalam hikmat Kristen, kesalehan, kebahagiaan dan kekudusan. Sedangkan kata menasihati berasal dari kata Yunani paraklēsis yang memiliki arti dipanggil mendekat, dinasehati, dikuatkan, dibuat nyaman, diberi instruksi, dan usaha untuk menyegarkan. Kata menghibur berasal dari kata paramuthia yang memiliki pengertian usaha yang dilakukan untuk menenangkan, menstimulasi keadaan menjadi tenang, menghibur, dan membuat

\footnotetext{
${ }^{8}$ Daniel Sutoyo, Paulus: Teolog, Penginjil, Pastor Dan Rasul Pejuang Iman Dalam Kristus
}

nyaman. Paulus terkait dengan nubuat di jemaat Korintus ini, bukan sekedar membicaraan mengenai isi nubuat itu tetapi Paulus juga menyoroti cara nubuat itu disampaikan dan tujuan di balik nubuat itu sendiri. Isi nubuat seharunya apa yang Tuhan inginkan bukan apa yang manusia inginkan.

Paulus dalam 1Tesalonika 4:15-17 juga berbicara tentang nubuat menyangkut akhir zaman. Peneliti mengkaji dua kata penting dari 1 Tesalonika 4:15-17 yaitu kata "kedatangan" dan kata "Tuhan." Kata "kedatangan" berasal dari kata Yunani parousia yang secara harafiah berarti datang, kedatangan, kedatangan Yesus di masa depan yang memegang kuasa penghakiman, dan secara resmi menyatakan kemuliaan Kerajaan Allah. Penyelidikan lebih jauh penggunaan kata parousia ini dan menemukan bahwa dalam papirus dan dalam dunia Yunani kata ini menunjuk pada kedatangan seorang kaisar, raja, gubernur, atau orang terkemuka ke kota atau provinsi tertentu. Untuk kedatangan seperti itu perlu dilakukan

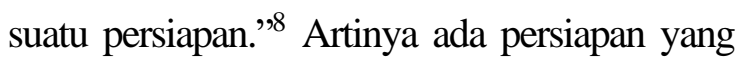
harusnya orang percaya lakukan terkait dengan kedatangan Tuhan ini.

Peneliti juga mencoba mengkaji kata "Tuhan.” Kata ini berasal dari bahasa Yunani kurios yang secara harafiah berarti Tuhan, Tuan yang menguasai seseorang, suatu gelar 
kehormatan yang ditujukan untuk Allah dan Mesias. Penjelasan Paulus tentang akhir zaman tidak keluar dari koridor penjelasan akhir zaman dari Perjanjian Lama maupun keempat Injil. Paulus sendiri meyakini bahwa akhir zaman itu pasti terjadi dan yang menjadi tokoh utama dalam akhir zaman adalah Yesus Kristus. Orang percaya akan melihat kehormatan dan kemuliaan Tuhan Yesus dalam peristiwa kedatangan Tuhan kembali. Bahkan peristiwa itu yang merupakan akhir dari peradaban manusia di bumi akan menarik semua mata tertuju pada peristiwa ini ketika terjadi.

Nubuat mengenai karunia Timotius yang dilakukan lewat penumpangan tangan (1Tim. 1:18; 4:14) merupakan contoh nubuatan lainnya dalam tulisan Paulus. Peneliti menganalisis empat kata dari bahasa asli terkait dengan nubuat di 1 Timotius 1:18 ini. Kata pertama yaitu kata "tugas" berasal dari bahasa Yunani paraggelia. Kata paraggelia memiliki pengertian memberikan tugas tetapi kata ini juga memiliki pengertian mengumumkan, memproklamirkan, dan memberikan perintah. Jelas disini bahwa tugas yang dimaksud Paulus untuk Timotius adalah sebauh perintah yang telah diploklamirkan atau diumumkan untuk Timotius lakukan. Artinya Timotius tidak bisa melalaikan, mengangap sepele, apalagi menghindar dari tugas ini karena ini adalah sebuah perintah.
Tentunya dalam konteks ini perintah yang bersifat ilahi.

Paulus mengunakan kata Yunani kata yang diterjemahkan dalam Alkitab bahasa Indonesia sesuai dengan itu. Kata ini mengandung pergertian sesuai dengan, melalui, dan langsung. Kata lain yang dianalisis adalah kata nubuat yang pada bagian sebelumnya juga sudah dianalisis yaitu berasal dari bahasa Yunani prophēteia. Kata prophēteia memberikan pengertian bahwa nubuat itu merupakan inspirasi ilahi dan merupakan sebuah deklarasi dari maksud dan tujuan Tuhan. Kata terakhir yang dianalisis disini adalah kata perjuangan yang berasal dari bahasa Yunani strateuomai. Kata strateuomai terkait dengan istilah militer berupa ekspedisi militer, memimpin prajurit untuk berperang, melakukan tugas militer, atau menjadi seorang prajurit.

Paulus dalam 1 Timotius 1:18 ini menjelaskan bahwa ada kesinambungan antara tugas Timotius dan nubuat. Kesinambungan disini yaitu tugas Timotius merupakan sebuah perintah ilahi yang terkait langsung dengan maksud dan tujuan Tuhan. Terhadap perintah ilahi ini Timotius harus bertindak sebagai seorang prajurit untuk masuk dalam peperangan dan membuka jalan sebagai prajurit yang terlibat dalam ekspedisi militer. Sebagai seorang pemimpin Timotius harus 
mempersiapkan orang percaya yang ada dalam area kepemimpinannya sebagai parajurit sorgawi untuk masuk dalam peperangan. Seorang prajurit yang pantang mundur disetiap pertempuran dan setiap sampai garis akhir dalam menjalankan iman dan keselamatan.

Paulus dalam 1 Timotius 4: 14 juga mengingatkan Timotius untuk jangan lalai mengunakan karunia Tuhan yang diberikan oleh nubuat melalui penunpangan tangan. Peneliti memilih tiga kata yang dianalisis untuk mendalami keterkaitan antara nubuan dan karunia pelayanan Timotius. Kata "lalai" berasal dari bahasa Yunani ameleō. Kata ameleō memiliki pengertian tidak merawat dengan hati-hati atau mengabaikan. Kata kedua yang dianalisis adalah kata "karunia." Karunia berasal dari bahasa Yunani charisma. Kata charisma ini memiliki pengertian kemurahan yang diterima tanpa usaha manusia yang terlibat, pemberian dari anugerah ilahi. Charisma juga berarti karunia yang luar biasa yang diberikan kepada orang percaya untuk memampukan melayani gereja Kristus yang beroperasi dalam jiwa oleh Roh Kudus. Kata terakhir yang dianalisis adalah kata diberikan yang berasal dari bahasa Yunani didōmi. Kata didōmi ini memiliki pengertian memberi, memberikan sesuatu kepada seseorang, dan memberikan sesuatu untuk keuntungan seseorang yang diberi.
Paulus memberikan pesan kepada Timotius agar merawat dengan hati-hati dan jangan abaikan karunia yang telah Tuhan berikan. Paulus memahami bahwa sebagai orang percaya dan pemimpin Timotius membutuhkan karunia untuk memampukan dalam melaksanakan tugas-tugas dan tangung jawab pelayanan. Mengkaji hubungan antara karunia dengan nubuat, dalam kasus Timotius berdasarkan penggalian dari bahasa Yunani ternyata karunia yang Timotius peroleh adalah hasil dari nubuat melalui penumpangan tangan sidang penatua. Seperti sudah dijelaskan pada bagian sebelumnya bahwa nubuat disini seperti kompas yang memberikan arah pelayanan Timotius.

Timotius bukanlah manusia super atau manusia setengah dewa. Sebagai manusia biasa Timotius mempunyai keterbatasan-keterbatasan.

Koneksi Timotius terbatas, kemampuan berpikir terbatas, sumber daya dan dana Timotius terbatas. Namun keterbatasan bukanlah halangan yang membuat Timotius gagal menggenapi panggilannya. Paulus menyadari bahwa kekuatan Timotius terbatas dan tanpa karunia Roh Timotius akan menyelesaikan segala pekerjaan pelayanannya dengan kedagingan yang tentu saja akan berakibat kurang baik. Ada satu pelajaran penting bagi orang percaya dan para pemimpin masa kini yaitu 
pekerjaan Roh hanya bisa dikerjakan dengan karunia Roh dan tidak bisa diselesaikan dengan cara daging.

Berdasarkan uraian tentang tulisan rasul Paulus di atas maka dapatlah disimpulkan dalam ajaran karunia nubuat rasul Paulus harus ada kelima hal ini. Pertama, dilakukan oleh orang yang lahir baru. Lahir baru yang peneliti maksudkan dalam tulisan ini adalah lahir baru yang pengertiannya mengacu pada surat-surat Paulus terutama terkait dalam konteks nubuatan. Rasul Paulus ketika berbicara karunia bernubuat dalam 1 Korintus 12 dan 1 Korintus 14 lebih suka orang percaya bernubuat dan menghidupi karunia nubuat ini untuk kepentingan pelayanan. Mengacu pada tulisan Paulus, adapun lahir baru yang peneliti maksudkan di sini adalah orang percaya yang telah menerima Tuhan Yesus sebagai Tuhan dan Juru Selamat. Serta mendedikasikan hidup untuk maksud dan tujuan Tuhan.

Kedua, memiliki sikap takut akan Tuhan ketika bernubuat. Paulus adalah orang yang keseluruhan hidup dan pengajarannya dibangun diatas dasar takut akan Tuhan. Paulus dalam 1 Korintus 14 dalam kaitan dengan nubuat memaknai

\footnotetext{
9 Yohanes Yotham, "Iman Dan Akal Ditinjau Dari Perspektif Alkitab,” Jurnal Simpson: Jurnal Teologi dan Pendidikan Agama Kristen 2, no. 1 (2015): 37-70, accessed October 20, 2019, https://journal.sttsimpson.ac.id/index.php/Js/article/ view/19.
}

takut akan Tuhan sebagai penyembahan, penghormatan, berharap, percaya, yang didalamnya ada kasih kepada Tuhan. ${ }^{9}$ Ketiga, dilakukan dalam suatu komunitas orang percaya. Adapun yang dimaksudkan dengan komunitas di sini yaitu kumpulan dari orang percaya yang secara geografis berada dalam satu wilayah dan yang secara rohani mengabungkan dan menundukkan diri dalam suatu kumpulan jemaat untuk hidup bagi Tuhan. Diucapkan dalam komunitas supaya nubuat yang diucapkan mengalami cek dan ricek dari orang percaya lainnya.

Keempat, digunakan untuk tujuan pelayanan. Pelayanan dalam pengertian di sini yaitu peran orang percaya terkait dengan bagaimana mengunakan karunia nubuatan untuk melaksanakan fungsinya sebagai bagian dari tubuh Kristus. Lewat karunia bernubuat ini orang percaya lain memahami, melaksanakan, dan menghidupi fungsi mereka dalam tubuh Kristus sehingga tubuh Kristus yaitu gereja mengalami pertumbuhan. Pertumbuhan merupakan efek alamiah dari kehadiran Roh Kudus dalam gereja. ${ }^{10}$ Kelima, hasil akhirnya adalah membangun kehidupan rohani jemaat. Nubuat dalam pandangan

\footnotetext{
${ }^{10}$ Junifrius Gultom, "Pneumatologi Amos Yong dan Refleksi Misiologi (Perspektif Pentakosta/Kharismatik Indonesia)," Jurnal Antusias 2, no. 4 (2013): 157-169, accessed October 20, 2019, https://sttintheos.ac.id/ejournal/index.php/antusias/article/view/29.
} 
Paulus adalah salah satu sarana yang Allah pakai dan juga yang dapat digunakan oleh orang percaya untuk membangun pertumbuhan rohani orang percaya lainnya (1 Kor. 14:3). Adapun yang dimaksudkan dengan membangun pertumbuhan rohani di sini adalah ketika orang percaya menggunakan karunia bernubuat untuk membangun orang percaya lainnya.

\section{Fenomena Bernubuat di Gereja}

\section{Beraliran Karismatik di Semarang}

Selama mengadakan penelitian, peneliti menemukan bahwa benar ada praktik-praktik bernubuat yang terjadi di gereja beraliran Karismatik se-kota Semarang. Karunia nubuat yang terjadi di gereja beraliran Karismatik yang terjadi pada prinsipnya dapatlah peneliti kelompokan dalam dua kategori yaitu yang alkitabiah dan yang ngeroh. ${ }^{11}$ Ada nubuatan-nubuatan yang diucapkan yang tentunya memenuhi standar kebenaran Alkitab yang merupakan dasar operasional dari karunia bernubuat. Nubuatan jenis ini peneliti kategorikan dalam kelompok nubuatan yang bersifat alkitabiah karena dapat ditelusuri sumbernya dalam Alkitab. Artinya ketika nubuat diucapkan maka akan melihat prinsip-prinsip yang Alkitab ajarkan. Contohnya dalam persekutuan

\footnotetext{
${ }^{11}$ Manurung, "Studi Analisis Kontekstual Ajaran Karunia Nubuat Rasul Paulus Sebagai Dasar Evaluasi Kritis Terhadap Fenomena Bernubuat Di
}

Youth seorang anggota Youth mendapatkan pernyataan mengenai seorang wanita yang hadir di ibadah tersebut. Setelah dikonseling oleh istri gembala ternyata benar bahwa memang telah terjadi sesuatu pelecehan terhadap wanita tersebut yang mengakibatkan luka yang mendalam.

Peneliti menemukan bahwa kelompok pemahaman Alkitabiah ini biasanya dimotori oleh orang percaya yang memiliki pengetahuan Alkitab yang kuat dan dapat dipertangguna jawabkan dihadapan Tuhan maupun akademis. Ketika peneliti mewawancarai salah satu narasumber menceritakan bahwa narasumber tersebut juga mempraktekkan pengurapan profetik untuk berbicara atas nama Tuhan kepada jemaat sesuai dengan prinsip-prinsip. Selain itu juga nara sumber ini menulis buku tentang nubuatan. Narasumber lain juga mengakui bahwa sangat percaya karunia bernubuat itu ada dan digereja yang beliau pimpin praktek karunia bernubuat itu ada. Bahkan peneliti menemukan bahwa salah satu STT yang dinaungi oleh gereja beraliran Karismatik memiliki mata kuliah tentang pelayanan profetik.

Kelompok ngeroh adalah kategori kedua yang peneliti temukan dalam Gereja Beraliran Karismatik Se-Kota Semarang", 325. 
mempraktekan karunia nubuat. Dimasukan dalam kategori ngeroh karena memang nubuat ini tidak dibangun dalam pemahaman Alkitab yang benar secara khusus dalam artikel ini berarti tidak dibangun berdasarkan pada ajaran karunia bernubuat yang rasul Paulus ajarkan. Nubuatan-nubuatan yang diucapkan yang kategori ngeroh ini sudah dibahas sebelumnya pada temuan hasil penelitian fenomena nubuat palsu.

Pemahaman ngeroh adalah pemahaman lain dalam mempraktekan karunia nubuat kedua yang peneliti temukan di kalangan gereja beraliran Karismatik sekota Semarang. Pemahaman ngeroh yang dimaksudkan disini adalah dimana praktek-praktek nubuatan yang dilakukan oleh orang percaya tersebut didasarkan bukan pada prinsip-prinsip yang Alkitab ajarkan mengenai karunia bernubuat tetapi berdasarkan apa yang orang tersebut anggap benar. Pemahaman ngeroh ini akhirnya melahirkan fenomena nubuat palsu. Kelompok pemahaman ngeroh ini adalah orang percaya yang tidak mau bertumbuh dalam firman. Artinya orang percaya dari kelompok ini mungkin menyukai membaca Alkitab tetapi terkait bagaimana menafsirkan Alkitab tersebut kelompok ini menafsirkannya semau dan semampunya. Dengan kata lain tidak mau mengupgrade diri dengan belajar di
Sekolah Teologi untuk mendapatkan pemahaman akan prinsip-prinsip penafsiran Alkitab yang benar sehingga bisa mempraktekan karunia bernubuat dengan benar.

Tabel- tabel berikut dibawah ini adalah hasil wawancara dengan enam orang nara sumber terkait fenomena karunia bernubuat di kalangan gereja beraliran Karismatik di Semarang :

Tabel 1

\begin{tabular}{|c|c|}
\hline Jela & an apakah karunia nubuat itu? \\
\hline $\mathrm{R} 1$ & Karunia dari Tuhan dari Roh \\
\hline & Kudus dimana seseorang \\
\hline & diberikan pernyataan tentang hal- \\
\hline & hal yang akan datang baik tentang \\
\hline & $\begin{array}{l}\text { seseorang atau suatu kondisi, } \\
\text { gereja, bangsa, dan sebagainya. }\end{array}$ \\
\hline $\mathrm{R} 2$ & Suatu kemampuan untuk \\
\hline & menyampaikan apa yang menjadi \\
\hline & isi hati Tuhan buat seseorang. \\
\hline R3 & Salah satu karunia Roh Kudus. \\
\hline & Karunia supranatural dimana \\
\hline & seseorang diilhami Roh Kudus \\
\hline & memberikan nasihat, dorongan \\
\hline & kadang teguran. \\
\hline $\mathrm{R} 4$ & Menyatakan dengan yakin dan \\
\hline & penuh kuasa suatu kebenaran \\
\hline & yang diyakini dari Alkitab. \\
\hline R5 & Pesan dari Allah untuk orang \\
\hline & percaya. \\
\hline & Kebenaran dari Allah yang \\
\hline & bersifat prediktif tentang masa \\
\hline & depan. \\
\hline R6 & Ramalan masa depan tentang \\
\hline & $\begin{array}{l}\text { sesuatu yang akan terjadi dimasa } \\
\text { depan yang berasal dari Allah. }\end{array}$ \\
\hline
\end{tabular}

Keterangan: R1 adalah inisial yang peneliti berikan pada responden pertama yang peneliti wawancarai. Begitu pula pengunaan inisial yang lainnya R2 s/d R6 
adalah para responden selanjutnya

berdasarkan kronologis waktu dalam

wawancara penelitian ini.

Berdasarkan data tabel 1 tersebut maka dapatlah disimpulkan bahwa menurut para narasumber karunia bernubuat itu adalah karunia yang diberikan Roh Kudus kepada seseorang berupa kemampuan untuk menyampaikan apa yang menjadi isi hati Tuhan yang terkait dengan suatu kondisi atau keadaan dimasa depan baik itu untuk seseorang, gereja, bangsa, dan lain sebagainya. Kesimpulan ini pada intinya mirip dengan pengertian yang penulis berikan mengenai karunia nubuat.

Tabel 2

\section{Jelaskan dasar Alkitab dari karunia} nubuat?

R1 1Korintus 14

R2 Ajaran-ajaran yang dikemukanan oleh rasul Paulus dalam jemaat di Korintus.

Seluruh Alkitab adalah dari

Kejadian sampai Wahyu adalah landasan operasional karunia nubuat.

R3 1Korintus 12-14.

R4 1Korintus 12-14.

R5 Kisah Para Rasul 11:28

Efesus 2:20

1Yohanes 4:1

1Tesalonika 5:20-21

R6 Kejadian 3.

Berdasarkan data tabel 2 tersebut maka dapatlah disimpulkan bahwa menurut para narasumber dasar Alkitab dari karunia bernubuat adalah keseluruhan Alkitab merupakan landasan operasional karunia bernubuat itu sendiri, terutama tulisan rasul Paulus dalam 1 Korintus . Pandangan para narasumber mengenai dasar Alkitab karunia bernubuat memiliki kesamaan dengan apa yang peneliti jabarkan dalam artikel ini yaitu tulisan Paulus terutama dalam 1 Korintus.

Tabel 3

\begin{tabular}{ll}
\hline $\begin{array}{l}\text { Sebutkan apa saja tujuan karunia } \\
\text { nubuat? }\end{array}$ \\
\hline R1 & $\begin{array}{l}\text { Membangun. } \\
\text { Menghibur. }\end{array}$ \\
& $\begin{array}{l}\text { Menasihati. } \\
\text { R2 }\end{array}$ \\
& $\begin{array}{l}\text { Membawa orang ke dalam } \\
\text { destiny Tuhan. }\end{array}$ \\
R3 & $\begin{array}{l}\text { Menasihati } \\
\text { Menghibur }\end{array}$ \\
R4 & $\begin{array}{l}\text { Mengajar kebenaran. } \\
\text { Untuk kemuliaan Tuhan. }\end{array}$ \\
& $\begin{array}{l}\text { Untuk membangun jemaat. } \\
\text { Meneguhkan jemaat. } \\
\text { Menghibur. }\end{array}$ \\
R5 & $\begin{array}{l}\text { Untuk membangun gereja-Nya. } \\
\text { Membangun. } \\
\text { R6 }\end{array}$ \\
& $\begin{array}{l}\text { Menasihati. } \\
\text { Menghibur. }\end{array}$ \\
\hline
\end{tabular}

Para narasumber menurut table 3 tersebut sepakat bahwa karunia nubuat memiliki tujuan untuk menasihati, menghibur, dan membangun jemaat sehingga jemaat hidup dalam destiny Tuhan. Para narasumber yang peneliti wawancarai adalah orang yang memiliki pemahaman bahwa karunia nubuat yang rasul Paulus ajarkan masih berlaku sampai saat ini. Ada yang mengajar mata kuliah Profetik sudah bertahun-tahun, ada yang membuat buku tentang penglihatan 
profetik. Pada intinya para nara sumber percaya dan menerapkan karunia nubuat dalam kehidupan rohani juga dalam pengembalaan mereka.

\section{Tabel 4}

Bagaimana fenomena nubuat yang menurut anda agak menyimpang dan meresahkan yang terjadi di Semarang sehingga bisa disebut nubuat palsu?

R1 Ada hamba Tuhan seminar di Semarang menyatakan Rapture tanggal 23 September 2017. Menubuatkan jemaat yang sakit sudah di ICU dinubuatkan melayani Tuhan ternyata meninggal.

Tiga orang menubuatkan gembala meninggal.

R2 Nubuat yang menyatakan bukan pilihan Tuhan gembala yang ditunjuk oleh sinode.

Seminar hamba Tuhan berinisial AT yang memprediksi kedatangan Tuhan.

Hamba Tuhan di Semarang yang mengajarkan fenomena alam seperti bloodmoon dan dikaitkan dengan Akhir Zaman atau kedatangan Kristus kedua kali. Menubuatkan kalau tidak mengembalikan perpuluhan kepada hamba Tuhan yang bernubuat tidak akan diberkati. Praktek kepalsuan profetik.

R3 Nubuat tidak akan ikut rapture. Nubuat cawan doa baru $3 / 4$ cawan penuh dan dalam 1 jam harus penuh agar hamba Tuhan berinisial PA yang meninggal dibangkitkan.

Nubuat jubah pengembalaan turun ke putri bungsu setelah hamba Tuhan meninggal.

R4 Menubuatkan teman hidup. Menubuatkan doa waktu orang sakit diperkirakan meninggal ternyata hidup lama.
Nubuat membangkitkan orang mati.

Nubuat akhir zaman pada tanggal tertentu di seminar hamba Tuhan di Semarang.

R5 Nubuat diluar Bahtera tidak selamat.

Nikah roh.

Nubuat tabut dicium dan disembah karena lambang kehadiran Tuhan.

Nubuat minta jadwal pelayanan. Mengaitkan bloodmoon dengan

Rapture.

Nubuat makan bunga urapan khusus tertentu dalam pelayanan. Berbicara dengan pemimpin yang sudah meninggal.

R6 Nubuat yang menyatakan bahwa gembala yang ditunjuk oleh sinode untuk menggantikan gembala yang sudah meninggal bukan tudung rohani dan mengakibatkan pemberontakan para staf dan menyebabkan perpecahan gereja. Nubuat tentang perpuluhan. Nubuat 2 saksi di Akhir Zaman.

Data tabel 4 tersebut menunjukan bahwa keenam narasumber yang peneliti wawancarai memiliki kerisauan yang sama dalam jawaban mereka terkait dengan adanya praktek-praktek nubuat yang terjadi di kalangan gereja beraliran Karismatik di Semarang yang sudah menyimpang dari yang Alkitab ajarkan sehingga perlu di evaluasi. Nubuat-nubuat ini tentu saja berdampak buruk bagi kesehatan rohani umat kalau diikuti. 
Evaluasi Fenomena Bernubuat di Gereja Beraliran Karismatik di Semarang

Para nabi adalah pendidik sosial dizamanya, mereka mengajari umat Allah untuk mempertanggung jawabkan gaya hidup mereka. ${ }^{12}$ Karunia nubuat harusnya dilakukan dengan bertanggung jawab. Melihat fakta dalam tabel 4 maka evaluasi terhadap fenomena bernubuat mutlak dilakukan oleh gereja beraliran Karismatik di Semarang. Evaluasi yang peneliti lakukan di sini bukan sekedar pada benar salahnya sebuah nubuat namun juga bertujuan mendidik orang percaya pentingnya sebuah nubuatan dievaluasi. Tabel-tabel di bawah ini adalah kumpulan jawaban para nara sumber dari pertanyaan peneliti yang mengunakan kelima indikator ajaran karunia nubuat rasul Paulus untuk mengevalusi nubuat:

\section{Tabel 5}

\begin{tabular}{ll}
\hline $\begin{array}{l}\text { Apakah nubuat yang agak menyimpang } \\
\text { tersebut diucapkan oleh orang yang lahir } \\
\text { baru? }\end{array}$ \\
\hline R1 & $\begin{array}{l}\text { Kemungkinan besar sudah } \\
\text { mengalami proses lahir baru }\end{array}$ \\
& $\begin{array}{l}\text { karena para hamba Tuhan. } \\
\text { R2 }\end{array}$ \\
& $\begin{array}{l}\text { Sudah lahir baru tapi tidak } \\
\text { bertumbuh dalam pengetahuan }\end{array}$ \\
& Firman. \\
R3 & Orang lahir baru bisa nyimpang. \\
R4 & Sudah lahir baru \\
R5 & Orang lahir baru yang melenceng. \\
R6 & Tidak lahir baru \\
\hline
\end{tabular}

${ }^{12}$ Mulyo Kadarmanto, "Mandat Profetik Pendidikan Kristen Di Era Revolusi Industri 4.0,"
Secara umum para narasumber sepakat bahwa orang yang mengucapkan nubuat-nubuat yang menyimpang itu adalah orang yang sudah lahir baru namun tidak mengupgrade diri dalam pemahaman Firman yang Alkitabiah. Dengan kata lain orang yang bernubuat ini adalah orang percaya yang sudah mengalami proses lahir baru namun malas untuk belajar di tempat yang benar semisal Sekolah Tinggi Teologi sehingga tidak bertumbuh dalam pemahaman Alkitab.

Tabel 6

\begin{tabular}{ll}
\hline $\begin{array}{l}\text { Benarkah ada sikap takut akan Tuhan } \\
\text { waktu nubuat yang menyimpang itu } \\
\text { diucapkan? }\end{array}$ \\
\hline R1 & $\begin{array}{l}\text { Harus ditelusuri. } \\
\text { R2 }\end{array}$ \\
& $\begin{array}{l}\text { Kalau yang disampaikan tidak } \\
\text { benar mereka seharusnya } \\
\text { bertobat. }\end{array}$ \\
& $\begin{array}{l}\text { Mereka tidak punya roh takut } \\
\text { akan Tuhan. }\end{array}$ \\
R3 $\quad \begin{array}{l}\text { Lebih tidak takut akan Tuhan } \\
\text { karena yang menguasai dia waktu }\end{array}$ \\
bernubuat kepentingan yang \\
bukan dari Tuhan. \\
R4 $\quad \begin{array}{l}\text { Sepertinya tidak takut akan Tuhan } \\
\text { karena ada kepentingan. }\end{array}$ \\
R5 $\quad \begin{array}{l}\text { Mereka tidak takut akan Allah } \\
\text { karena kalau mereka memiliki } \\
\text { takut akan Allah harus cek cepat- }\end{array}$ \\
cepat dan bertobat. \\
Menurut saya tidak
\end{tabular}

Orang yang takut akan Tuhan adalah orang yang mengasihi Tuhan dan mendedikasikan hidupnya untuk penyembahan dan penghormatan kepada

STULOS (Jurnal Teologi) 16, no. 2 (2018): 159178. 
Tuhan karena mengasihi Tuhan. Melihat jawaban tabel 6 secara umum para narasumber menjawab bahwa orang yang bernubuat menyimpang tersebut adalah orang tidak takut akan Tuhan dan dikuasai kepentingan lain waktu bernubuat. Hal ini bisa di lihat bahwa kalau orang tersebut takut akan Tuhan pasti mau dicek kalau misalnya salah mau bertobat.

Tabel 7

\section{Benarkah nubuat palsu itu diucapkan} dalam sebuah komunitas orang percaya?

R1 Pada umumnya.

R2 Biasanya dalam komunitas tapi juga disampaikan pribadi.

R3 Dalam Komunitas.

R4 Iya.

R5 Umumnya dikomunitas.

R6 Biasanya dalam suatu komunitas.

Indikator selanjutnya dalam ajaran Paulus untuk mengevaluasi nubuat adalah apakah nubuat itu disampaikan di sebuah komunitas. Paulus menghendaki supaya setiap nubuat di sampaikan dama komunitas agar orang percaya lain bisa mendengar, menyimak, mengadakan cek dan ricek terhadap nubuat tersebut. Jawaban narasumber dalam tabel 7 secara umum menyatakan bahwa nubuat itu di sampaikan dalam sebuah komunitas.

\footnotetext{
${ }^{13}$ Harls Evan R. Siahaan, “Aktualisasi Pelayanan Karunia Di Era Digital,” EPIGRAPHE: Jurnal
}

Namun tujuan mengapa disampaikan di komunitas tidak tercapai karena tidak ada cek dan ricek dari orang percaya lain.

Tabel 8

\begin{tabular}{|c|c|}
\hline \multicolumn{2}{|c|}{$\begin{array}{l}\text { Benarkah tujuan nubuat palsu tersebut } \\
\text { untuk pelayanan? }\end{array}$} \\
\hline $\mathrm{R} 1$ & $\begin{array}{l}\text { Campur-campur ada yang } \\
\text { pelayanan ada pribadi. }\end{array}$ \\
\hline R2 & $\begin{array}{l}\text { Bukan untuk pelayanan tapi untuk } \\
\text { kepentingan pribadi. }\end{array}$ \\
\hline R3 & $\begin{array}{l}\text { Dibaliknya ada kepentingan } \\
\text { pribadi. }\end{array}$ \\
\hline $\mathrm{R} 4$ & Tergantung hati yang bernubuat. \\
\hline R5 & $\begin{array}{l}\text { Untuk mengembangkan kerajaan } \\
\text { yang bernubuat bukan untuk } \\
\text { kerajaan Tuhan. }\end{array}$ \\
\hline R6 & $\begin{array}{l}\text { Namanya aja nubuat palsu pasti } \\
\text { bukan untuk pelayanan ada } \\
\text { embel-embel dan motivasi lain. } \\
\text { Memperkaya diri sendiri. }\end{array}$ \\
\hline
\end{tabular}

Para narasumber sepakat bahwa ada motivasi lain berupa kepentingan pribadi ketika nubuatan yang menyimpang itu diucapkan. Pelayanan dalam bentuk apapun pada dasarnya adalah sebuah bentuk pengabdian, ungkapan syukur kepada Tuhan karena anugerahNya. ${ }^{13}$ Ketika kepentingan pribadi mulai menunggangi nubuat maka nubuat itu bukan lagi murni untuk kepentingan Tuhan. Apalagi kalau kepentingan diri itu berupa memperkaya diri akan sangat berakibat merusak bukan saja pelayanan melainkan juga umat Tuhan.

Teologi dan Pelayanan Kristiani 1, no. 1 (January 29, 2018): 23-38. 
Tabel 9

\begin{tabular}{|c|c|}
\hline \multicolumn{2}{|c|}{$\begin{array}{l}\text { Apakah hasil akhir dari nubuat palsu } \\
\text { tersebut membangun kehidupan rohani } \\
\text { orang percaya? }\end{array}$} \\
\hline R1 & $\begin{array}{l}\text { Kalau yang benar dari Tuhan } \\
\text { secara umum pasti membangun } \\
\text { beda kalau yang palsu tidak } \\
\text { membangun. }\end{array}$ \\
\hline $\mathrm{R} 2$ & $\begin{array}{l}\text { Tidak akan pernah membangun } \\
\text { justru meruntuhkan. }\end{array}$ \\
\hline R3 & Lebih banyak merusak. \\
\hline R4 & Lebih banyak tidak membangun. \\
\hline R5 & $\begin{array}{l}\text { Ujungnya merusak dan memecah } \\
\text { belah gereja. }\end{array}$ \\
\hline R6 & $\begin{array}{l}\text { Tidak membangun hanya } \\
\text { memecah belah jemaat dan } \\
\text { merusak jemaat. }\end{array}$ \\
\hline
\end{tabular}

Secara umum narasumber pada table 9 menjawab bahwa akibat dari nubuat yang menyimpang itu tidak membangun jemaat atau orang percaya melainkan hanya akan merusak dan memecah belah orang percaya.

Pada bagian sebelumnya sudah di bahas bahwa ada dua kelompok yang mempraktikan karunia bernubuat di kalangan gereja beraliran Karismatik di Semarang yaitu kelompok Alkitabiah dan kelompok ngeroh. Evaluasi kelompok Alkitabiah adalah suatu evaluasi yang dilakukan dengan menerapkan prinsipprinsip Alkitab. Artinya kelompok ini ketika mempraktekan karunia bernubuat mempertimbangkan aspek-aspek yang Alkitab ajarkan termasuk juga aspek evaluasi untuk menguji segala sesuatu. Kelompok Alkitabiah sangat menekankan proses evaluasi dari setiap pernyataanpernyataan nubuatan yang dikemukanan agar terjadi cek dan ricek.

Evaluasi kelompok Alkitabiah ini menunjukan bagaimana seharusnya karunia bernubuat itu dievaluasi sehingga terhindar dari kepentingan-kepentingan yang bukan kepentingan Tuhan. Misalkan ketika orang percaya mendapatkan sesuatu pesan ilahi terkait dengan seseorang yang hadir, orang percaya tersebut tidak langsung mengungkapkan hal itu. Tetapi memberitahukan hal tersebut pada gembala yang memiliki otoritas akan pesan ilahi tersebut. Terlihat jelas bahwa selain memberikan kesempatan untuk dicek dan ricek, ada penghormatan kepada otoritas yang Tuhan taruh dalam gereja lokal tidak sembarangan melanggar otoritas yang sudah Tuhan tetapkan.

Evaluasi dalam kelompok ngeroh sangat berbeda dari evaluasi dari kelompok alkitabiah. Kelompok ngeroh tidak menganggap perlu untuk nubuatan atau karunia bernubuat itu dievaluasi. Hal ini tentu saja tidak terlepas dari pemahaman yang terbangun dalam kelompok ngeroh bahwa nubuat itu asalnya dari Tuhan selain pasti benar, siapa yang bisa mengevaluasi Tuhan? Jelas terlihat bahwa dalam cara pandang kelompok ini nubuat tidak perlu dievaluasi. Pada umumnya dalam kelompok ngeroh, nubuatan itu keluar dari 
para pemimpin kelompok yang sudah terkenal memiliki karunia bernubuat dan sering mempraktekan karunia ini.

Peneliti lebih lanjut mengamati bahwa walaupun jelas-jelas nubuatan yang diucapkan itu tidak memiliki landasan pijakan prinsip-prinsip penafsiran Alkitab tetap saja nubuat itu tidak dievaluasi. Misalnya ketika seorang pendeta mengajar bahwa Tuhan segera datang karena satu tanda sudah digenapi yaitu air menjadi darah. Ketika belakangan diketahui bahwa penyebab air menjadi darah karena buangan limbah industri namun hamba Tuhan itu tidak meralat pengajaran atau nubuatan yang disampaikan. Ini memperlihatkan bahwa kesombongan dan harga diri adalah penghalang utama kelompok ngeroh untuk dievaluasi. Adalagi contoh lain mengenai nubuatan dua saksi di akhir zaman yang nyata-nyata waktu salah satu saksi dalam nubuatan itu meninggal tidak ada yang meralat atau mengevaluasi nubuat itu.

\section{KESIMPULAN}

Gereja beraliran Karismatik adalah gereja yang terbuka pada karunia rohani. Karunia nubuat adalah karunia rohani yang Tuhan berikan untuk memperlengkapi orang percaya yaitu untuk membangun, menasihati, menghibur serta mengarahkan orang percaya pada tujuan Tuhan. Namun pada kenyataannya, karunia nubuat ini sering disalah mengerti bahkan ada oknum tertentu yang menyalah gunakan karunia ini, bukan lagi untuk melayani Tuhan melainkan untuk kepentingan pribadi. Maka dari itu, orang percaya di kalangan gereja beraliran Karismatik baik yang di kota Semarang maupun di tempat lainnya perlu memperlengkapi diri dengan memahami ajaran karunia nubuat yang rasul Paulus ajarkan. Sehingga dapat menerapkan prinsip-prinsip dalam ajaran rasul Paulus tersebut dan menjadikannya alat ukur untuk mengevaluasi setiap nubuat.

\section{DAFTAR PUSTAKA}

Ang, Paul, and Christina Ang. Charisma. Yogyakarta: Andi Offset, 2013.

Creswell, John W. Penelitian Kualitatif Dan Design Riset. Yogyakarta: Pustaka Pelajar, 2015.

Gultom, Junifrius. "Pneumatologi Amos Yong dan Refleksi Misiologi (Perspektif Pentakosta/Kharismatik Indonesia)." Jurnal Antusias 2, no. 4 (2013): 157-169. Accessed October 20, 2019. https://sttintheos.ac.id/ejournal/index.php/antusias/article/vie $\mathrm{w} / 29$.

Kadarmanto, Mulyo. "Mandat Profetik Pendidikan Kristen Di Era Revolusi Industri 4.0." STULOS (Jurnal Teologi) 16, no. 2 (2018): 159-178.

Manurung, Kosma. "Studi Analisis Kontekstual Ajaran Karunia Nubuat Rasul Paulus Sebagai Dasar Evaluasi Kritis Terhadap Fenomena Bernubuat Di Gereja Beraliran Karismatik SeKota Semarang." STT Berita Hidup, 2018.

Siahaan, Harls Evan R. "Aktualisasi 
Pelayanan Karunia Di Era Digital." EPIGRAPHE: Jurnal Teologi dan Pelayanan Kristiani 1, no. 1 (January 29, 2018): 23-38.

Soesilo, Yushak. "Pengalaman Pribadi Dengan Roh Kudus Sebagai Indikator Kualitas Pelayanan." Jurnal Antusias 1, no. 3 (September 1, 2011): 109-117. Accessed March 4, 2018. http://sttintheos.ac.id/ejournal/index.php/antusias/article/vie $\mathrm{w} / 79 / 78$.

Suharso. "Kekhasan Eskhatologi Rasul Paulus." EL-SHADDAY (Jurnal Teologi) 1, no. 1 (2017): 65-75.

Susanta, Yohanes Krismantyo. "Menjadi Sesama Manusia' Persahabatan Sebagai Tema Teologis Dan Implikasinya Bagi Kehidupan Bergereja." DUNAMIS: Jurnal
Teologi dan Pendidikan Kristiani 2, no. 2 (April 23, 2018): 103-118.

Sutoyo, Daniel. Paulus: Teolog, Penginjil, Pastor Dan Rasul Pejuang Iman Dalam Kristus. Sukoharjo: Born Win's Publishing, 2012.

"The Charismatic Movement." Jurnal Antusias 1, no. 2 (2011): 29-40. Accessed October 20, 2019. https://sttintheos.ac.id/ejournal/index.php/antusias/article/vie w/82.

Yotham, Yohanes. "Iman Dan Akal Ditinjau Dari Perspektif Alkitab." Jurnal Simpson: Jurnal Teologi dan Pendidikan Agama Kristen 2, no. 1 (2015): 37-70. Accessed October 20, 2019.

https://journal.sttsimpson.ac.id/index. $\mathrm{php/Js/article/view/19.}$ 